\title{
ГЕНЕТИЧНІ МАРКЕРИ ЦУКРОВОГО ДІАБЕТУ 2 ТИПУ
}

\begin{abstract}
Вступ. Цукровий діабет 2 типу (ЦД2) є глобальною проблемою охорони здоров'я у зв'язку зі швидкими культурними та соціальними змінами, постарінням населення, посиленням урбанізації, зміною харчування, зменшенням фрізичної активності. Деякі фрактори ризику можна контролювати, наприклад режим харчування та ожиріння, інші, такі, як стать, вік, генетика, перебувають поза нашим контролем. Вважають, що цукровий діабет 2 типу є полігенним розладом, який розвивається через складну взаємодію між декількома генами та фракторами навколишнього середовища. Першим доказом ролі генетичних маркерів у розвитку цукрового діабету 2 типу були дослідження, проведені в другій половині ХХ ст. на близнюках у багатодітних сім'ях. Перші гени-кандидати виявлено для рідкісних фрорм цукрового діабету (неонатальний, мітохондріальний ЦД, МODY). На даний час відомо чимало генетичних маркерів Цд2, однак патогенетичний зв'язок більшості з них ще потрібно підтвердити. Проте це лише незначна частка генетичної складової хвороби. Темпи дослідження складної генетики ЦД2 протягом останнього десятиліття були вражаючими. На даний час відомо понад 300 локусів, які тісно пов'язані із Цд2. Найбільш дослідженими і такими, що становлять вагомий науковий інтерес, є гени KCNJ11, TCF7L2, PPARG, IRS1, PON 1, SLC30A8, FTO ma TNFa. Варто відзначити, що роль генів у патогенезі цукрового діабету не однозначна і потребує подальшого дослідження.

Мета дослідження - проаналізувати сучасні літературні джерела про генетичні маркери, які беруть участь у механізмах розвитку цукрового діабету 2 типу.

Висновки. Аналіз літературних джерел обірунтовує актуальність дослідження генетичних фракторів у патогенезі цукрового діабету 2 типу. Визначення ролі поліморфізму генів у розвитку і прогресуванні цукрового діабету 2 типу відкриє шлях для нових підходів до діагностики, стратифрікації, моніторингу, профрілактики та лікування цього захворювання.
\end{abstract}

КЛЮЧОВІ СЛОВА: генетичні маркери; цукровий діабет 2 типу; поліморфізм генів.

Цукровий діабет 2 типу (ЦД2) є глобальною проблемою охорони здоров'я у зв'язку зі швидкими культурними та соціальними змінами, постарінням населення, посиленням урбанізації, зміною харчування, зменшенням фрізичної активності. Кожна одинадцята доросла людина у всьому світі на даний час страждає від цукрового діабету, 90 \% з них мають ЦД2 [1]. За оцінками А. В. Kaiser та співавт., у 2018 р. у світі зареєстровано 500 млн випадків Цд2, при цьому автори зазначають, що його поширеність буде збільшуватись до 2028 р., особливо в країнах із низьким рівнем доходу [2]. За останні два десятиліття зростаюча поширеність ЦД2 призвела до понад 4,9 млн смертей [3]. У цілому Цд2 став однією з провідних причин втрати працездатності та смерті [4].

Цукровий діабет 2 типу характеризується диссрункцією острівців підшлункової залози та (c) В. А. Мусієнко, М. І. Марущак, 2019. резистентністю до інсуліну в перифреричних тканинах [4]. До основних фракторів етіологічного ризику ЦД2 належать вік, ожиріння, сімейний анамнез, етнічна приналежність, малорухомий спосіб життя та неправильне харчування [5]. Ці фрактори, очевидно, відіграють головну роль у розвитку діабету, проте вони мають різний вплив, оскільки при однакових етіологічних чинниках не у всіх осіб розвивається ЦД2 [6]. Тому вважають, що ЦД2 є полігенним розладом, який розвивається через складну взаємодію між декількома генами та фракторами навколишнього середовища. Темпи дослідження складної генетики Цд2 протягом останнього десятиліття були вражаючими. На даний час відомо понад 300 локусів, які тісно пов'язані із ЦД2 $[7,8]$.

Тому метою нашого дослідження було проаналізувати сучасні літературні джерела про генетичні маркери, які беруть участь у механізмах розвитку цукрового діабету 2 типу. 
Ген KCNJ11 (англ. Potassium voltage-gated channel subfamily J member 11 ) локалізований на хромосомі 11p15.1, є членом сімейства генів калієвих каналів. Завдяки позиції та фрункції гена в регуляції секреції інсуліну, KCNJ11 привернув значну увагу як один з генів, що сприяють розвитку ЦД2. Він кодує протеїн Kir6.2, що складається із 190 амінокислот та утворює КАТР-канал (adenosine triphosphate-sensitive $\mathrm{K}+$ ), який відіграє ключову роль у секреції інсуліну. На сьогодні відомо, що КАТР-канали існують у багатьох тканинах, таких, як скелетні м'язи, гладкі м'язи судин та серця. Цей канал через метаболізм глюкози контролює секрецію та вироблення інсуліну [9]. Поліморфізм гена KCNJ11 E23K, що також відомий як rs5219, був пов'язаний із ЦД2 у кількох великих дослідженнях, і дану знахідку підтвердили декілька останніх досліджень асоціації, пов'язаних з геномом (дослідження GWAS) [10]. Поліморфрізм E23K впливає на чутливість до АТФ КАТР-каналу; гомозиготні носії генотипу КК демонструють двократну знижену чутливість до АТФ [11]. КАТР-канали є мішенню для сульфонілсечовини, препаратів, які застосовують для лікування діабету, закриваючи канал і викликаючи секрецію інсуліну [12].

Ген TCF7L2 (англ. Transcription factor 7 like 2) також відомий як локус TCF4 на хромосомі 10q25.2-25.3 і кодує фрактор транскрипції, що містить групу високої мобільності, яка бере участь у сигнальному шляху Wnt [13]. Довжина поліпептидного ланцюга протеїну становить 619 амінокислот. Механізм, за допомогою якого він сприяє патогенезу Цд2, недостатньо вивчено [14]. Ген TCF7L2 вважають одним із найважливіших генів-кандидатів, що відіграють головну роль у гомеостазі глюкози в крові та фрункції $\beta$-клітин [15]. Сильну асоціацію TCF7L2 із ЦД2 спочатку було виявлено в популяції Ісландії, а згодом - у датського та американського населення [16]. Подальші дослідження було проведено для різних етнічних груп та зосереджено на 5-ти одномолекулярних поліморфізмах (rs12255372, rs7903146, rs7901695, rs11196205 i rs7895340) TCF7L2 [17]. Перше дослідження GWAS у популяції Франції показало сильний взаємозв'язок ЦД2 та TCF7L2. Послідовність результатів його асоціації із ЦД2, що спостерігається під час багатьох досліджень різних етнічних груп, свідчить про універсальний внесок цього гена в розвиток ЦД2. Його взаємозв'язок, поряд з іншими генами ЦД2, було також підтверджено під час наступних досліджень GWAS [18].

Ген PPARG (англ. Peroxisome proliferator activated receptor gamma) розташований на хромосомі 3р25.2 та кодує рецептор, що активує пролісрерацію пероксисом гамма. Довжина поліпеп- тидного ланцюга протеїну становить 505 амінокислот. Цей ген широко вивчали, оскільки він важливий у метаболізмі адипоцитів та ліпідів. Крім того, PPARG $€$ мішенню для гіпоглікемічних препаратів, відомих як тіазолідиндіони [19]. Одна з фрорм гена PPARy (Pro) знижує чутливість до інсуліну та збільшує ризик розвитку ЦД2 у кілька разів. Цей варіант дуже поширений у більшості населення. Приблизно 98 \% європейців мають хоча б одну копію алеля Pro. Поліморфізм гена PPARG (Pro12Ala, rs1801282) був пов'язаний із зменшенням індексу маси тіла, підвищенням чутливості до інсуліну та зниженням ризику розвитку ЦД2 [12]. Цю асоціацію підтвердили декілька останніх досліджень GWAS [20].

Ген IRS1 (англ. Insulin receptor substrate 1) розташований на хромосомі 2q36.3 та кодує однойменний протеїн. Довжина поліпептидного ланцюга протеїну становить 1242 амінокислоти. $€ 4$ члени родини IRS, які схожі за своєю будовою (IRS1, IRS2, IRS3 та IRS4) [21]. Коли інсулін зв'язується зі своїм рецептором на клітинній поверхні, IRS1 фросфорилюється та активує фоосфатидилінозитол-3-кіназу. Це ініціює каскад внутрішньоклітинної сигналізації, що призводить до різних відповідей клітиною. Однією з таких відповідей є активація рецептора GLUT (транспорту глюкози), що призводить до збільшення поглинання глюкози клітиною [22]. Хворі на ЦД2 мають знижену експресію та фрункцію IRS1 у жирових клітинах [23]. Поліморфізм Gly972Arg $€$ найбільш часто досліджуваним варіантом IRS1 [24]. Поліморсрізми Pro170Arg i Met209Thr також пов'язані із цД2 та асоціюються зі зниженням фоосфатидилінозитол-3-кіназної активності, що призводить до інсулінорезистентності різного ступеня вираження [25]. Нещодавно дослідники показали, що IRS1 пов'язаний не лише із Цд2 у різних популяціях, він може мати значну кореляцію з діабетичними ускладненнями, особливо 3 ішемічною хворобою серця та ожирінням [26-28].

Ген PON 1 (англ. Paraoxonase 1) розташований на хромосомі 7q21.3 та кодує протеїн параоксоназу 1. Довжина поліпептидного ланцюга протеїну становить 355 амінокислот. Сироваткова параоксоназа 1 - кальцієзалежний гідролітичний ензим, який трапляється в різних видів ссавців. Ген PON 1 належить до сімейства, що складається 3 3-х сироваткових параоксоназ (PON 1, PON 2 та PON 3), проте параоксоназа 1 залишається найпопулярнішим членом цієї родини [29]. Спочатку дані ензими називали естеразами, але пізніше вони стали загальновідомими як параоксонази завдяки їх здатності до детоксикації органофосфратного з'єднання параоксон [30]. Ген PON 1 відіграє важливу роль в антиоксидантному захисті організму, гідролізує 
токсичні метаболіти різних органофросфорних інсектицидів, здатний до гідролізу широкого спектра фоосфорорганічних субстратів і лактонів, а також ряду складних есрірів ароматичної карбонової кислоти. Основними наслідками тривалого окиснювального ураження $€$ розвиток $\beta$-клітинної диссрункції, порушення толерантності до глюкози та мітохондріальна диссрункція [31]. Окиснювальний стрес та пероксидне окиснення ліпідів сприяють виникненню і прогресуванню діабету та його ускладнень [31]. Під час досліджень було виявлено 2 поширених поліморфрізми в ділянці кодування (в позиціях 55 та 192), які впливають на активність і концентрацію PON 1 [32]. Поліморфізм лейцину/метіоніну в положенні 55 (L55M) збільшує активність параоксона понад 50 \% у гомозиготній фрормі (MM) порівняно 3 LL та LM [31]. Показано, що поліморфізм глутаміну/аргініну в положенні 192 (Q192R) впливає на активність PON 1, зокрема ізоформа Q192 гідролізує параоксон і метаболізує окиснені ліпопротеїни низької щільності ефективніше, ніж ізосрорма R192 [33]. Частоти алелей Q192R i L55M та ензимна активність PON 1, а також сприйнятливість до розвитку певних захворювань, пов'язаних з параоксоназами, відрізняються між популяціями [34].

Ген SLC30A8 (англ. Solute carrier family 30 member 8) розташований на хромосомі 8q24.11 та кодує однойменний протеїн. Довжина поліпептидного ланцюга протеїну становить 369 амінокислот. Цей протеїн полегшує накопичення цинку із цитоплазми у внутрішньоклітинні везикули в гранулах секреторного шляху секреції інсуліну. Результати дослідження GWAS показали, що загальний алель C (R325) у поліморфізмі rs13266634 сильно пов'язаний із зменшенням вивільнення інсуліну та сприйнятливістю до Цд2 [35]. Асоціація була підтверджена в європейців та азіатських груп населення [36-40]. Інший поширений поліморфізм rs11558471 A/G гена SLC30A8, зокрема алель A, також асоціюється із ЦД2 серед азіатських груп $[41,42]$.

Ген FTO (англ. FTO, alpha-ketoglutarate dependent dioxygenase) розташований на хромосомі 16q12.2 та кодує одноймений протеїн. Довжина поліпептидного ланцюга протеїну становить 505 амінокислот. Точної фрізіологічної фрункції гена не встановлено. Ген FTO експресується в різних тканинах, зокрема гіпоталамусі, печінці, м'язовій тканині, адипоцитах і $\beta$-клітинах підшлункової залози [43]. Дослідження GWAS підтвердило, що поліморфізм rs9939609 у межах першого інтрона гена FTO сприяє розвитку ЦД2 у європейського населення через вплив на індекс маси тіла, тоді як інші дані показали, що варіанти генів FTO збільшують ризик розвитку ЦД2 незалежно від індексу маси тіла [44]. 3 того часу кілька досліджень підтвердили сильну асоціацію FTO rs9939609 з ожирінням у різних етнічних групах, окрім китайців та афрроамериканців [44]. Дослідження, проведене у 2016 р., показало, що вплив варіантів FTO на сприйнятливість до ЦД2 у японських чоловіків опосередковується через вплив FTO на індекс маси тіла [45]. Дослідження, проведене у 2018 р. на жінках з ожирінням, підтвердило асоціацію кількох варіантів FTO, включаючи rs9939609, із ЦД2 та ожирінням [46].

Ген TNF $\alpha$ (англ. Tissue necrosis factor alpha) розташований на хромосомі 6р21.3 та кодує позаклітинний протеїн - фрактор некрозу пухлини $\alpha$ (TNF $\alpha)$. Він стимулює вивільнення інтерлейкіну 6 і безпосередньо інгібує сигнал інсуліну фоссрорилюванням серину 307 у залишку IRS1, а також індукує ядерний фрактор транскрипції (NF) - kappa B, який викликає апоптоз $\beta$-клітин підшлункової залози. Ген TNF $\alpha$ збільшує підвищений рівень сироваткових вільних жирних кислот (FFA) [47]. Високий рівень TNFa асоціюється з резистентністю до інсуліну, впливаючи на чутливість рецепторів до інсуліну в адипоцитах і гепатоцитах. Ген TNF $\alpha$ також зумовлює стійкість до інсуліну в скелетних м'язах, погіршуючи поглинання глюкози [48]. Гіперінсулінемія індукує посилене вироблення TNF $\alpha$ в сироватці крові пацієнтів 3 ожирінням та Цд2. Асоціацію алеля TNFa G308A з патогенезом ЦД2 можна пояснити тим, що алель 308А відповідає за посилену вдвічі транскрипцію TNF $\alpha$ порівняно 3 алелем 308G, що призводить до підвищення сироваткового рівня TNFa [49]. Результати генетичних досліджень щодо асоціації поліморфізму TNFa G308A із ЦД2, рівнем TNFa в сироватці крові, інсулінорезистентністю та ожирінням суперечливі. Встановлено, що асоціація між TNF $\alpha$ G308A і ЦД2 є позитивною в населення Японії та пацієнтів старшого віку з діабетом з Нідерландів [50]. Та варто відмітити, що не виявлено значної асоціації між ЦД2 та поліморфізмом G308A TNF $\alpha$ в населення багатьох країн світу [51].

Аналіз літературних джерел обґрунтовує актуальність дослідження генетичних фракторів у патогенезі цукрового діабету 2 типу. Визначення ролі поліморфізму генів у розвитку і прогресуванні цукрового діабету 2 типу відкриє шлях для нових підходів до діагностики, стратифрікації, моніторингу, профілактики та лікування цього захворювання. 


\section{СПИСОК ЛІТЕРАТУРИ}

1. Zheng Y. Global etiology and epidemiology of type 2 diabetes mellitus and its complications / Y. Zheng, S. Ley, F. Hu. // Nat. Rev. Endocrinol. -2018. - No. 14. P. 88-98

2. Kaiser A. B. Global prevalence of type 2 diabetes over the next ten years (2018-2028) / A. B. Kaiser, N. Zhang, W. Van Der Pluijm // Diabetes. - 2018. No. 67 (1). - P. 202

3. Saddik B. Diabetic patients' willingness to use tele-technology to manage their disease - A descriptive study / B. Saddik, N. Al-Dulaijan // Online J. Public Health Inform. - 2015. - No. 7 (2).

4. Integrative analysis of superenhancer SNPs for type 2 diabetes / W. Sun, S. Yao, J. Tang [et al.] // PLoS ONE. - 2018. - No. 13 (1).

5. Forouhi N. G. Epidemiology of diabetes / N. G. Forouhi, N. J. Wareham // Medicine. - 2019. - No. 47 (1). P. 22-27.

6. Ali O. Genetics of type 2 diabetes / O. Ali // World J Diabetes - 2013. - No. 4 (4). - P. 114-123.

7. An expanded genome-wide association study of type 2 diabetes in Europeans / R. A. Scott, L. J. Scott, R. Mägi [et al.] // Diabetes. - 2017. - No. 66. - P. 28882902.

8. Fine-mapping of an expanded set of type 2 diabetes loci to single-variant resolution using high-density imputation and islet-specific epigenome maps / A. Mahajan, D. Taliun, M. Thurner [et al.] // Nature Genetics. - 2018. - No. 50 (11). - P. 1505-1513.

9. Association of KCNJ11 Genetic Variations with Risk of Type 2 Diabetes Mellitus (T2DM) in North Indian Population. [Electronic resource] : Preprints, 2019070089 / V. Khan., D. Bhatt., S. Khan [et al.]. - 2019. - Access mode : https://www.preprints.org/manuscript/201907. 0089/v1

10. A genome-wide association study identifies novel risk loci for type 2 diabetes / R. Sladek, G. Rocheleau, J. Rung [et al.] // Nature. - 2007. - No. 445 (7130). P. 881-885.

11. Targeted overactivity of beta cell K(ATP) channels induces profound neonatal diabetes / J. C. Koster, B. A. Marshall, N. Ensor [et al.] // Cell. - 2000. No. 100 (6). - P. 645-654.

12. Fakruddin M. Genetics of type 2 diabetes: a review / M. Fakruddin // Journal of Current and Advance Medical Research. - 2019. - No. 6 (1). - P. 59-63.

13. Meta-analysis of association between TCF7L2 polymorphism rs7903146 and type 2 diabetes mellitus / W. Ding, L. Xu, L. Zhang [et al.] // BMC Medical Genetics. - 2018. - No. 19 (1). - P. 19-38.

14. TCF7L2 variation predicts hyperglycemia incidence in a French general population: the data from an epidemiological study on the insulin resistance syndrome (DESIR) study / S. Cauchi, D. Meyre, H. Choquet [et al.] // Diabetes. - 2006. - No. 55 (11). P. 3189-3192.

15. Migliorini A. Beyond association: A functional role for Tcf7l2 in beta-cell development / A. Migliorini, H. Lickert // Mol. Metab. - 2015. - No. 4 (5). - P. 365-366.

16. Association of rs7903146 TCF7L2 (C/T) Gene Polymorphism and Type 2 Diabetes Mellitus in Pakistani Population / M. Dalhat, H. Bello, B. Ibrahim, A. Labbo // Journal of Applied Life Sciences International. - 2017. No. 14 (4). - P. 1-7.
17. Possible role of TCF7L2 in the pathogenesis of type 2 diabetes mellitus / Z. Huang, Y. Liao, R. Huang [et al.] // Biotechnology \& Biotechnological Equipment. 2018. - No. 32 (4). - P. 830-834.

18. Ip W. The involvement of the wnt signaling pathway and TCF7L2 in diabetes mellitus: The current understanding, dispute, and perspective / W. Ip, Y. Chiang, T. Jin // Cell Biosci. - 2012. - No. 2 (1). - P. 28.

19. Kersten S. Roles of PPARs in health and disease / S. Kersten, B. Desvergne, W. Wahli // Nature. - 2000. No. 405 (6785). - P. 421-424.

20. Replication of genome-wide association signals in UK samples reveals risk loci for type 2 diabetes / E. Zeggini, M. Weedon, C. Lindgren [et al.] // Science. 2007. - No. 316(5829). - P. 1336-1341.

21. Muoio D. M. Mechanisms of disease:Molecular and metabolic mechanisms of insulin resistance and beta-cell failure in type 2 diabetes / D. M. Muoio, C. B. Newgard // Nat. Rev. Mol. Cell Biol. - 2008. No. 9 (3). - P. 193-205.

22. 5'-AMP-activated protein kinase phosphorylates IRS-1 on Ser-789 in mouse C2C12 myotubes in response to 5-aminoimidazole-4-carboxamide riboside / S. Jakobsen, D. Hardie, N. Morrice, H. Tornqvist // J. Biol. Chem. 2001. - No. 276 (50). - P. 46912-46916.

23. The combined role of allelic variants of IRS-1 and IRS-2 genes in susceptibility to type2 diabetes in the Punjabi Pakistani subjects / A. ljaz, S. Babar, S. Sarwar [et al.] // Diabetol. Metab. Syndr. - 2019. - No. 11. P. 64.

24. Association of IRS1 genetic variants with glucose control and insulin resistance in type 2 diabetic patients from Bosnia and Herzegovina / L. Mahmutovic, T. Bego, M. Sterner [et al.] // Drug Metab. Pers. Ther. - 2019. No. 34 (1).

25. Шалімова А. С. Асоціації поліморфізму гена irs-1 3 порушеннями ліпідного спектра крові при гіпертонічній хворобі і супутньому цукровому діабеті 2-го типу / А. С. Шалімова // Семейная медицина. 2015. - № 3. - C. 102-104.

26. Association between insulin receptor substrate-1 polymorphisms and high platelet reactivity with clopidogrel therapy in coronary artery disease patients with type 2 diabetes mellitus / D. Zhang, X. Zhang, D. Liu [et al.] // Cardiovasc. Diabetol. - 2016. - No. 15. - P. 50.

27. Lavin D. P. IRS proteins and diabetic complications / D. P. Lavin, M .F. White, D. P. Brazil // Diabetologia. - 2016. - No. 59 (11). - P. 2280-2291.

28. The FOXO1 gene-obesity interaction increases the risk of type 2 diabetes mellitus in a Chinese han population / L. Gong, R. Li, W. Ren [et al.] // J. Korean Med. Sci. - 2017. - No. 32 (2). - P. 264-271.

29. The three-gene paraoxonase family: physiologic roles, actions and regulation / L. Precourt, D. Amre, M. Denis [et al.] // Atherosclerosis. - 2011. - No. 214 (1). P. 20-36.

30. Mackness M. Human paraoxonase-1 (PON1): Gene structure and expression, promiscuous activities and multiple physiological roles / M. Mackness, B. Mackness // Gene. - 2015. - No. 567 (1). - P. 12-21.

31. Levy D. Paraoxonases activities and polymorphisms in elderly and old-age diseases: An overview / D. Levy, C. Reichert, S. Bydlowski // Antioxidants (Basel). - 2019. - No. 8 (5). 
32. Shunmoogam N. Paraoxonase (PON)-1: a brief overview on genetics, structure, polymorphisms and clinical relevance / N. Shunmoogam, P. Naidoo, R. Chilton // Vasc. Health Risk Manag. - 2018. - No. 14. P. 137-143.

33. Measurement of paraoxonase (PON1) status as a potential biomarker of susceptibility to organophosphate toxicity / L. Costa, T. Cole, A. Vitalone, C. Furlong // Clin. Chim. Acta. - 2005. - No. 352 (1-2). - P. 37-47.

34. Bacchetti T. The role of paraoxonase in cancer / T. Bacchetti, G. Ferretti, A. Sahebkar // Semin. Cancer Biol. - 2019. - No. 56. - P. 72-86.

35. The diabetes-susceptible gene SLC30A8/ZnT8 regulates hepatic insulin clearance / M. Tamaki, Y. Fujitani, A. Hara [et al.] // J. Clin. Invest. - 2013. - No. 123 (10). P. 4513-4524.

36. Gu H. F. Genetic, epigenetic and biological effects of zinc transporter (SLC30A8) in type 1 and type 2 diabetes / H. F. Gu // Curr. Diabetes Rev. - 2017. No. 13 (2). - P. 132-140.

37. The influence of rare genetic variation in SLC30A8 on diabetes incidence and beta-cell function / L. K. Billings, K. A. Jablonski, R. J. Ackerman [et al.] // J. Clin. Endocrinol. Metab. - 2014. - No. 99 (5). - P. E926930.

38. Validation of the association of TCF7L2 and SLC30A8 gene polymorphisms with post-transplant diabetes mellitus in Asian Indian population / I. Khan, P. Jahan, Q. Hasan, P. Rao // Intractable Rare Dis. Res. 2015. - No. 4 (2). - P. 87-92.

39. Contribution of SLC30A8 variants to the risk of type 2 diabetes in a multi-ethnic population: a case control study / S. Salem, R. Saif-Ali, I. Ismail [et al.] // BMC Endocr. Disord. - 2014. - No. 14. - P. 2.

40. Association between SLC30A8 rs13266634 polymorphism and type 2 diabetes risk: A meta-analysis / L. Cheng, D. Zhang, L. Zhou [et al.] // Med. Sci. Monit. 2015. - No. 21. - P. 2178-2189.

41. Association study of genetic variants in eight genes/loci with type 2 diabetes in a Han Chinese population / Y. Lin, P. Li, L. Cai [et al.] // BMC Med. Genet. 2010. - No. 11. - P. 97.

42. Total zinc intake may modify the glucose-raising effect of a zinc transporter (SLC30A8) variant: a 14-cohort meta-analysis / S. Kanoni, J. Nettleton, M. Hivert [et al.] // Diabetes. - 2011. - No. 60 (9). - P. 2407-2416.

43. Association of polymorphic markers of genes FTO, KCNJ11, CDKAL1, SLC30A8, and CDKN2B with type 2 diabetes mellitus in the Russian population / A. G. Nikitin, V. Y. Potapov, O. I. Brovkina [et al.] // PeerJ. 2017. - No. 5. - P. e3414.

44. Common FTO rs9939609 variant and risk of type 2 diabetes in Palestine / A. Sabarneh S. Ereqat S. Cauchi [et al.] // BMC Med Genet. - 2018. - No. 19 (1). P. 156.

45. FTO gene polymorphism is associated with type 2 diabetes through its effect on increasing the maximum BMI in Japanese men / Y. Kamura, S. Iwata, M. Maeda [et al.] // PLoS One. - 2016. - No. 11 (11). - P. e0165523.

46. Association between FTO gene polymorphisms and type 2 diabetes mellitus, serum levels of apelin and androgen hormones among Iranian obese women I F. Ghafarian-Alipour, S. Ziaee, M. Ashoori [et al.] // Gene. - 2018. - No. 641. - P. 361-366.

47. Moller D. E. Potential role of TNF-alpha in the pathogenesis of insulin resistance and type 2 diabetes / D. E. Moller // Trends Endocrinol. Metab. - 2000. No. 11 (6). - P. 212-217.

48. Insulin resistance induced by tumor necrosis factor-alpha in myocytes and brown adipocytes / M. Lorenzo, S. Fernandez-Veledo, R. Vila-Bedmar [et al.] // J. Anim. Sci. - 2008. - No. 86 (14). - P. E94-104.

49. The C-174G promoter polymorphism of the IL-6 gene affects energy expenditure and insulin sensitivity / A. Kubaszek, J. Pihlajamaki, K. Punnonen [et al.] // Diabetes. - 2003. - No. 52 (2). - P. 558-561.

50. Association of TNF-alpha gene promoter C-857T polymorphism with higher serum LDL cholesterol levels and carotid plaque formation in Japanese patients with type 2 diabetes / M. Yamashina, Y. Kaneko, C. Maesawa [et al.] // Tohoku J. Exp. Med. - 2007. - No. 211 (3). P. 251-258.

51. Nadeem A. Inter-ethnic variations in association of TNF-alpha G308a single nucleotide polymorphism with type 2 diabetes mellitus - a review / A. Nadeem // Journal of Diabetes, Metabolic Disorders \& Control. - 2017. No. 4 (2).

\section{REFERENCES}

1. Zheng, Y., Ley, S. \& Hu, F. (2018). Global aetiology and epidemiology of type 2 diabetes mellitus and its complications. Nat. Rev. Endocrinol., 14, 88-98.

2. Kaiser, A.B., Zhang, N., \& Van Der Pluijm, W. (2018). Global prevalence of type 2 diabetes over the next ten years (2018-2028). Diabetes, 67 (1), 202.

3. Saddik, B., \& Al-Dulaijan, N. (2015). Diabetic patients' willingness to use tele-technology to manage their disease - A descriptive study. Online J. Public Health Inform, 7 (2), e214. doi:10.5210/ojphi.v7i2.6011

4. Sun, W. Yao, S., Tang, J., Liu, S., Chen, J., \& Deng, D. (2018). Integrative analysis of superenhancer SNPs for type 2 diabetes. PLOS ONE, 13 (1).
5. Forouhi, N.G., \& Wareham, N. J. (2019). Epidemiology of diabetes. Medicine, 47 (1), 22-27.

6. Ali, O. (2013). Genetics of type 2 diabetes. World J. Diabetes, 4 (4), 114-123.

7. Scott, R.A., Scott, L.J., Mägi, R., Marullo, L., Gaulton, K.J. Kaakinen, M., ... et al. (2017). Diabetes genetics replication and meta-analysis (DIAGRAM) consortium. An expanded genome-wide association study of type 2 diabetes in Europeans. Diabetes, 66 (11), 28882902. doi:10.2337/db16-1253

8. Mahajan, A., Taliun, D., Thurner, M., Robertson, N.R., Torres, J.M., Rayner, N. W., . . McCarthy, M.I. (2018). Fine-mapping type 2 diabetes loci to single-variant 
resolution using high-density imputation and islet-specific epigenome maps. Nat. Genet., 50 (11), 1505-1513. doi:10.1038/s41588-018-0241-6

9. Khan, V., Bhatt, D., Khan, S., VERMA, A.K., Hasan, R., Rafat, S., ... Dev, K. (2019). Association of KCNJ11 genetic variations with risk of type 2 diabetes mellitus (T2DM) in North Indian population. Preprints, 2019070089 doi: 10.20944/preprints201907.0089.v1

10. Sladek, R., Rocheleau, G., Rung, J., Dina, C., Shen, L., Serre, D., ... Froguel, P. (2007). Agenome-wide association study identifies novel risk loci for type 2 diabetes. Nature, 445 (7130), 881-885. doi:10.1038/ nature05616

11. Koster, J.C., Marshall, B.A., Ensor, N., Corbett, J.A., \& Nichols, C.G. (2000). Targeted overactivity of beta cell K(ATP) channels induces profound neonatal diabetes. Cell, 100 (6), 645-654. doi:10.1016/s00928674(00)80701-1

12. Fakruddin, M. (2019). Genetics of type 2 diabetes: A review. Journal of Current and Advance Medical Research, 6 (1), 59-63.

13. Ding, W., Xu, L., Zhang, L., Han, Z., Jiang, Q., Wang, Z. \& Jin, S. (2018). Meta-analysis of association between TCF7L2 polymorphism rs7903146 and type 2 diabetes mellitus. BMC Medical Genetics, 19 (1).

14. Cauchi, S., Meyre, D., Choquet, H., Dina, C. Born, C., Marre, M., ... Group, D.S. (2006). TCF7L2 variation predicts hyperglycemia incidence in a French general population: the data from an epidemiological study on the Insulin Resistance Syndrome (DESIR) study. Diabetes, 55 (11), 3189-3192. doi:10.2337/db06-0692

15. Migliorini, A., \& Lickert, H. (2015). Beyond association: A functional role for Tcf712 in beta-cell development. Mol. Metab., 4 (5), 365-366. doi:10.1016/j. molmet.2015.03.002

16. Dalhat, M., Bello, H., Ibrahim, B. \& Labbo, A. (2017). Association of rs7903146 TCF7L2 (C/T) Gene polymorphism and type 2 diabetes mellitus in Pakistani population. Journal of Applied Life Sciences International, 14 (4), 1-7.

17. Huang, Z., Liao, Y., Huang, R., Chen, J. \& Sun, H. (2018). Possible role of TCF7L2 in the pathogenesis of type 2 diabetes mellitus. Biotechnology \& Biotechnological Equipment, 32 (4), 830-834.

18. Ip, W., Chiang, Y.T., \& Jin, T. (2012). The involvement of the wnt signaling pathway and TCF7L2 in diabetes mellitus: The current understanding, dispute, and perspective. Cell Biosci. , 2 (1), 28. doi:10.1186/20453701-2-28

19. Kersten, S., Desvergne, B., \& Wahli, W. (2000). Roles of PPARs in health and disease. Nature, 405 (6785), 421-424. doi:10.1038/35013000

20. Zeggini, E., Weedon, M.N., Lindgren, C.M., Frayling, T.M., Elliott, K.S., Lango, H., ... Hattersley, A.T. (2007). Replication of genome-wide association signals in UK samples reveals risk loci for type 2 diabetes. Science, 316 (5829), 1336-1341. doi:10.1126/ science. 1142364

21. Muoio, D.M., \& Newgard, C.B. (2008). Mechanisms of disease: Molecular and metabolic mechanisms of insulin resistance and beta-cell failure in type 2 diabetes. Nat. Rev. Mol. Cell Biol., 9(3), 193-205. doi:10.1038/nrm2327

22. Jakobsen, S.N., Hardie, D.G., Morrice, N., \& Tornqvist, H.E. (2001). 5'-AMP-activated protein kinase phosphorylates IRS-1 on Ser-789 in mouse C2C12 myotubes in response to 5-aminoimidazole-4-carboxamide riboside. J. Biol. Chem., 276 (50), 46912-46916. doi:10.1074/jbc.C100483200

23. ljaz, A., Babar, S., Sarwar, S., Shahid, S.U., \& Shabana. (2019). The combined role of allelic variants of IRS-1 and IRS-2 genes in susceptibility to type2 diabetes in the Punjabi Pakistani subjects. Diabetol. Metab. Syndr., 11, 64. doi:10.1186/s13098-019-0459-1

24. Mahmutovic, L., Bego, T., Sterner, M., Gremsperger, G., Ahlqvist, E., Velija Asimi, Z., ... Semiz, S. (2019). Association of IRS1 genetic variants with glucose control and insulin resistance in type 2 diabetic patients from Bosnia and Herzegovina. Drug Metab. Pers. Ther., 34 (1). doi:10.1515/dmpt-2018-0031

25. Shalimova, A. (2015). Asotsiatsii polimorfizmu hena irs-1 z porushenniamy lipidnoho spektra krovi pry hipertonichnii khvorobi i suputnomu tsukrovomu diabeti 2-ho typu [Association of IRS>1 gene polymorphism with violations of blood lipid spectrum in patients with essential hypertension and concomitant type 2 diabetes]. Semeynaya medytsyna - Family Medicine, 3, 102-104 [in Ukrainian].

26. Zhang, D., Zhang, X., Liu, D., Liu, T., Cai, W., Yan, C., \& Han, Y. (2016). Association between insulin receptor substrate-1 polymorphisms and high platelet reactivity with clopidogrel therapy in coronary artery disease patients with type 2 diabetes mellitus. Cardiovasc. Diabetol., 15, 50. doi:10.1186/s12933-016-0362-0

27. Lavin, D.P., White, M.F., \& Brazil, D.P. (2016). IRS proteins and diabetic complications. Diabetologia, 59 (11), 2280-2291. doi:10.1007/s00125-016-4072-7

28. Gong, L., Li, R., Ren, W., Wang, Z., Wang, Z., Yang, M., \& Zhang, S. (2017). The FOXO1 Gene-Obesity Interaction Increases the Risk of Type 2 Diabetes Mellitus in a Chinese Han Population. J. Korean Med. Sci., 32 (2), 264-271. doi:10.3346/jkms.2017.32.2.264

29. Precourt, L.P., Amre, D., Denis, M.C., Lavoie, J.C., Delvin, E., Seidman, E., \& Levy, E. (2011). The three-gene paraoxonase family: physiologic roles, actions and regulation. Atherosclerosis, 214 (1), 20-36. doi:10.1016/j. atherosclerosis.2010.08.076

30. Mackness, M., \& Mackness, B. (2015). Human paraoxonase-1 (PON1): Gene structure and expression, promiscuous activities and multiple physiological roles. Gene, 567 (1), 12-21. doi:10.1016/j.gene.2015.04.088

31. Levy, D., Reichert, C.O., \& Bydlowski, S.P. (2019). Paraoxonases activities and polymorphisms in elderly and old-age diseases: An overview. Antioxidants (Basel), 8 (5). doi:10.3390/antiox8050118

32. Shunmoogam, N., Naidoo, P., \& Chilton, R. (2018). Paraoxonase (PON)-1: a brief overview on genetics, structure, polymorphisms and clinical relevance. Vasc. Health Risk Manag., 14, 137-143. doi:10.2147/ VHRM.S165173

33. Costa, L.G., Cole, T.B., Vitalone, A., \& Furlong, C.E. (2005). Measurement of paraoxonase (PON1) status as a potential biomarker of susceptibility to organophosphate toxicity. Clin. Chim. Acta, 352 (1-2), 37-47. doi:10.1016/j. cccn.2004.09.019

34. Bacchetti, T., Ferretti, G., \& Sahebkar, A. (2019). The role of paraoxonase in cancer. Semin. Cancer Biol., 56, 72-86. doi:10.1016/j.semcancer.2017.11.013

35. Tamaki, M., Fujitani, Y., Hara, A., Uchida, T., Tamura, Y., Takeno, K., ... Watada, H. (2013). The diabe- 
tes-susceptible gene SLC30A8/ZnT8 regulates hepatic insulin clearance. J. Clin. Invest., 123 (10), 4513-4524. doi:10.1172/JCl68807

36. Gu, H.F. (2017). Genetic, epigenetic and biological effects of zinc transporter (SLC30A8) in type 1 and type 2 diabetes. Curr. Diabetes Rev., 13 (2), 132-140. do i:10.2174/1573399812666151123104540

37. Billings, L.K., Jablonski, K.A., Ackerman, R.J., Taylor, A., Fanelli, R.R., McAteer, J.B., . . . Diabetes Prevention Program Research Group, R. (2014). The influence of rare genetic variation in SLC30A8 on diabetes incidence and beta-cell function. J. Clin. Endocrinol. Metab., 99 (5), E926-930. doi:10.1210/jc.2013-2378

38. Khan, I.A., Jahan, P., Hasan, Q., \& Rao, P. (2015) Validation of the association of TCF7L2 and SLC30A8 gene polymorphisms with post-transplant diabetes mellitus in Asian Indian population. Intractable Rare Dis. Res., 4 (2), 87-92. doi:10.5582/irdr.2015.01008

39. Salem, S.D., Saif-Ali, R., Ismail, I.S., Al-Hamodi, Z., \& Muniandy, S. (2014). Contribution of SLC30A8 variants to the risk of type 2 diabetes in a multi-ethnic population: a case control study. BMC Endocr. Disord., 14, 2. doi:10.1186/1472-6823-14-2

40. Cheng, L., Zhang, D., Zhou, L., Zhao, J., \& Chen, B. (2015). Association between SLC30A8 rs13266634 polymorphism and type 2 diabetes risk: A meta-analysis. Med. Sci. Monit., 21, 2178-2189. doi:10.12659/MSM.894052

41. Lin, Y., Li, P., Cai, L., Zhang, B., Tang, X., Zhang, X., ... Yang, Z. (2010). Association study of genetic variants in eight genes/loci with type 2 diabetes in a Han Chinese population. BMC Med. Genet., 11, 97. doi:10.1186/1471-2350-11-97

42. Kanoni, S., Nettleton, J. A., Hivert, M.F., Ye, Z., van Rooij, F.J., Shungin, D., ... Dedoussis, G.V. (2011). Total zinc intake may modify the glucose-raising effect of a zinc transporter (SLC30A8) variant: a 14-cohort metaanalysis. Diabetes, 60 (9), 2407-2416. doi:10.2337/ $\mathrm{db} 11-0176$

43. Nikitin, A.G., Potapov, V.Y., Brovkina, O.I., Koksharova, E.O., Khodyrev, D.S., Philippov, Y.I., ... Shestakova, M.V. (2017). Association of polymorphic markers of genes FTO, KCNJ11, CDKAL1, SLC30A8, and CDKN2B with type 2 diabetes mellitus in the Russian population. PeerJ., 5, e3414. doi:10.7717/peerj.3414
44. Sabarneh, A., Ereqat, S., Cauchi, S., AbuShamma, O., Abdelhafez, M., Ibrahim, M., \& Nasereddin, A. (2018). Common FTO rs9939609 variant and risk of type 2 diabetes in Palestine. BMC Med. Genet., 19 (1), 156. doi:10.1186/s12881-018-0668-8

45. Kamura, Y., Iwata, M., Maeda, S., Shinmura, S., Koshimizu, Y., Honoki, H., ... Tobe, K. (2016). FTO gene polymorphism is associated with type 2 diabetes through its effect on increasing the maximum BMI in Japanese men. PLoS One, 11 (11), e0165523. doi:10.1371/journal. pone.0165523

46. Ghafarian-Alipour, F., Ziaee, S., Ashoori, M.R., Zakeri, M.S., Boroumand, M.A., Aghamohammadzadeh, N., ... Zarghami, N. (2018). Association between FTO gene polymorphisms and type 2 diabetes mellitus, serum levels of apelin and androgen hormones among Iranian obese women. Gene, 641, 361-366. doi:10.1016/j. gene.2017.10.082

47. Moller, D.E. (2000). Potential role of TNF-alpha in the pathogenesis of insulin resistance and type 2 diabetes. Trends Endocrinol. Metab., 11 (6), 212-217. doi:10.1016/s1043-2760(00)00272-1

48. Lorenzo, M., Fernandez-Veledo, S., Vila-Bedmar, R., Garcia-Guerra, L., De Alvaro, C., \& Nieto-Vazquez, I. (2008). Insulin resistance induced by tumor necrosis factor-alpha in myocytes and brown adipocytes. J. Anim. Sci., 86 (14), E94-104. doi:10.2527/jas.20070462

49. Kubaszek, A., Pihlajamaki, J., Punnonen, K., Karhapaa, P., Vauhkonen, I., \& Laakso, M. (2003). The C-174G promoter polymorphism of the IL-6 gene affects energy expenditure and insulin sensitivity. Diabetes, 52 (2), 558-561. doi:10.2337/diabetes.52.2.558

50. Yamashina, M., Kaneko, Y., Maesawa, C. Kajiwara, T., Ishii, M., Fujiwara, F., ... Satoh, J. (2007). Association of TNF-alpha gene promoter C-857T polymorphism with higher serum LDL cholesterol levels and carotid plaque formation in Japanese patients with type 2 diabetes. Tohoku J. Exp. Med., 211 (3), 251-258. doi:10.1620/tjem.211.251

51. Nadeem, A. (2017). Inter-ethnic variations in association of TNF-alpha G308a single nucleotide polymorphism with type 2 diabetes mellitus - a review. Journal of Diabetes, Metabolic Disorders \& Control, 4 (2). doi: 10.15406/jdmdc.2017.04.00105

\section{ТЕРНОПОЛЬСКИЙ НАЦИОНАЛЬНЫЙ МЕДИЦИНСКИЙ УНИВЕРСИТЕТ ИМЕНИ И. Я. ГОРБАЧЕВСКОГО
У. И. Марущак МОЗ УКРАИНЫ}

\section{ГЕНЕТИЧЕСКИЕ МАРКЕРЫ САХАРНОГО ДИАБЕТА 2 ТИПА}

\section{Резюме}

Вступление. Сахарный диабет 2 типа (СД2) является глобальной проблемой здравоохранения в связи с быстрыми культурными и социальными изменениями, старением населения, усилением урбанизации, изменением питания, уменьшением фризической активности. Некоторые фракторы риска можно контролировать, например режим питания и ожирение, другие, такие, как пол, возраст, генетика, находятся вне нашего контроля. Считается, что сахарный диабет 2 типа является полигенным расстройством, которое развивается через сложное взаимодействие между несколькими генами и фракторами 
окружающей среды. Первым доказательством роли генетических маркеров в развитии сахарного диабета 2 типа были исследования, проведенные во второй половине XX в. на близнецах в многодетных семьях. Первые гены-кандидаты обнаружено для редких фрорм сахарного диабета (неонатальный, митохондриальный СД, МODY). В настоящее время известно немало генетических маркеров СД2, однако патогенетическую связь большинства из них еще нужно подтвердить. Тем не менее это лишь незначительная часть генетической составляющей болезни. Темпы исследования сложной генетики СД2 в течение последнего десятилетия были впечатляющими. В настоящее время известно более 300 локусов, которые тесно связаны с СД2. Наиболее исследованными и такими, которые представляют весомый научный интерес, являются гены KCNJ11, TCF7L2, PPARG, IRS1, PON 1, SLC30A8, FTO и TNFa. Cmoum отметить, что роль генов в патогенезе сахарного диабета не однозначна и требует дальнейшего исследования.

Цель исследования - проанализировать современные литературные источники о генетических маркерах, которые участвуют в механизмах развития сахарного диабета 2 типа.

Выводы. Анализ литературных источников обосновывает актуальность исследования генетических фракторов в патогенезе сахарного диабета 2 типа. Определение роли полиморфизма генов в развитии и прогрессировании сахарного диабета 2 типа откроет путь для новых подходов к диагностике, стратификации, мониторингу, профрилактике и лечению этого заболевания.

КЛЮЧЕВЫЕ СЛОВА: генетические маркеры; сахарный диабет 2 типа; полиморфизм генов.

V. A. Musiienko, M. I. Marushchak

I. HORBACHEVSKY TERNOPIL NATIONAL MEDICAL UNIVERSITY

\section{GENETIC MARKERS OF TYPE 2 DIABETES}

Introduction. Type 2 diabetes (T2D) is a global health problem due to rapid cultural and social change, aging of the population, increasing urbanization, changing nutrition, and reduced physical activity. Some risk factors can be controlled, such as diet and obesity, while others, such as sex, age, genetics, are beyond our control. Diabetes mellitus type 2 is believed to be a polygenic disorder that develops through a complex interaction between several genes and environmental factors. The first evidence of the role of genetic markers in the development of type 2 diabetes was twin studies in large families conducted in the second half of the XX century. The first candidate genes were identified for rare forms of diabetes (neonatal, mitochondrial $C D, M O D Y$ ). There are currently many genetic markers for T2D known, but the pathogenetic link between most of them remains to be confirmed. However, this is only a small fraction of the genetic component of the disease. The pace of research into the complex genetics of T2D has been impressive over the last decade. Currently, there are over 300 loci that are closely related to T2D. The most studied and those of considerable scientific interest are the KCNJ11, TCF7L2, PPARG, IRS1, PON 1, SLC3OA8, FTO and TNF-alpha genes. It is worth noting that the role of genes in the pathogenesis of diabetes is ambiguous and needs further investigation.

The aim of the study - to analyze current literary sources about genetic markers that are involved in the mechanisms of type 2 diabetes.

Conclusions. Analysis of literature sources substantiates the relevance of the study of genetic factors in the pathogenesis of type 2 diabetes. Defining the role of gene polymorphism in the development and progression of type 2 diabetes will open the way for new approaches to the diagnosis, stratification, monitoring, prevention and treatment of this disease.

KEY WORDS: genetic markers; type 2 diabetes; gene polymorphism.

Отримано 24.10.19

Адреса для листування: М. І. Марущак, Тернопільський національний медичний університет імені І. Я. Горбачевського МОз України, майдан Волі, 1, Тернопіль, 46001, Україна, e-mail: marushchak@tdmu.edu.ua. 